\section{The challenges of}

\section{research in \\ forest biology}

\section{T. T. KOZLOWSKI}

Deportment of Forestry University of Wisconsin Madison, Wisconsin

Les défits de la recherche en biologie forestière. Il est fréquent de constater cette tendance à vouloir généraliser et simplifier la nature et les conditions régissant la croissance de l'arbre. Il existe cependant une grande variabilité entre la croissance des arbres poussant en zone tropicale et tempérée, entre les gymnospermes et les angiospermes, entre les arbres à porosité circulaire et diffuse, tout comme entre espèces à l'intérieur de ces grands groupes; cette variation subsiste entre individus d'une même espèce, allant jusqu'aux différentes parties d'un même arbre. Bien que les conditions de croissance aient été souvent reliées à de simples facteurs intrinsèques au milieu, toute une accumulation de faits montre que cette croissance est complexe et suppose tout un réseau d'interactions entre facteurs internes et externes. La pratique sylvicole et les changements du milieu font sentir leur influence sur la croissance des tiges et sur certains proc essus physiologiques. Cette importance du contrôle de la croissance de l'arbre est bien démontrée au moyen du comportement longuement étudié des arbres soumis à des variations du milieu. Il est prioritaire de poursuivre des recherches de base en foresterie, en relation étroite avec la recherche en biologie forestière et les autres sciences touchant le domaine de plants. Des exemples de problèmes de recherche prioritaires comprennent 1/ les effets de la pollution industrielle et des biocides (herbicides, fungicides, insecticides, etc.) sur la physiologie de l'arbre; 2/ les effets des déficiences en eau et leur contrôle sur les arbres; $3 /$ les implications physiologiques sur la qualité du matériel des pépinières forestières; 4/ le contrôle de la reproduction.

Condensation of Keynote Address given at the First North American Forest Biology Workshop, Michigan State University, East Lansing, Michigan on 5 August 1970. Publication approved by Director of Research, College of Agricultural and Life Sciences, University of Wisconsin.
In considering the future of forest biology and some directions in which I believe it should be heading I will deliberately set my own experience against the background of cognate research in biological disciplines other than forestry. At the outset I would like to emphasize that forest biologists have a truly exciting calling because their experimental organism, the perennial woody plant, is a fascinating and unique object for study if only because it represents the world's largest and oldest living things. Like all multicellular organisms, it requires integration and coordination of growth of its separated and morphologically differentiated organs. The fact that trees well over 200 feet tall, for example, can exist for a few thousand years must pose some very interesting problems on the mechanisms of translocation of sufficient amounts of food, water, hormonal growth regulators, and minerals both upward and downward over such tremendous distances. This is all the more remarkable when we consider that the avenue for food transport in a tree stem is a layer of the phloem only a fraction of a millimeter thick. Hence, from a physiological standpoint, trees must continuously be precisely coordinated to survive.

I also want to emphasize the extreme variability in growth characteristics and physiological activity of different woody plants, even in the same environment. The really exciting thing about tree growth is that we find tremendous variability between tropical and temperatezone trees, between gymnosperms and angiosperms, between ring porous and diffuse porous trees, species within these groups, individual trees within species, and in different parts of the same tree, in coordination of physiological activity and growth responses. Under increasing environmental stress, which often is a product of plant competition, it is the marked variability in growth of the various components of a dynamic ecosystem, such as a forest, which accounts for differences in competitive ability and plays a significant role in succession.

\section{Complexity of tree growth}

There is growing recognition by practising foresters and researchers of the extreme complexity of the nature and control of tree growth. There are several kinds of evidence for this. In the past much emphasis was put on single environmental factors in growth control. However, changes in a single or several environmental factors often are rather remote in space and time from ultimate growth response of a tree. A change in soil moisture may or may not affect growth, depending on whether water gets into the tree and whether it is rapidly lost and thereby affects cell turgor. Cell or tissue turgor is causally related to and close to the event, growth. Soil moisture per se is not. The importance of internal growth control is especially well shown in forest trees by their large time-lag responses to environmental changes. A closer correlation often exists between shoot elongation and environment of the year of bud formation than with environment of the year of expansion of the bud into a shoot (Kozlowski 1971a). The release of a tree by thinning a stand not only tends to increase total wood increment but also produces a more tapered tree by greater stimulation of wood production toward the stem base than at upper stem levels. However, the response to thinning at the stem base may not be apparent for a few years, emphasizing dramatically that some internal physiological adjustments are slow in large trees.

We have tended to oversimplify the nature and control of cambial growth. For a long time studies on cambial growth were concerned largely with xylem production only. Many early researchers assumed that annual xylem production preceded phloem production. However, recent studies show that in a number of species seasonal phloem differentiation may precede xylem differentiation by as much as several weeks. This emphasizes that overall cambial growth is complicated and should be broken down into its several components for study. More detailed information is needed for different species of h. trees on maturation of overwintering xylem and phloem cells, division 
in the cambial sheath to produce xylem and phloem cells, increase in size of cambial derivatives, increase in cell wall thickness, transition from earlywood to latewood, and division of cambial and ray cells to provide for increase in circumference of the cambial cylinder.

Many problems exist in evaluating effects of environmental factors on cambial growth. An abrupt change in environment does not alter cambial growth similarly in all species in a stand or even among trees of the same species. This may be the result of differences among trees in exposure, crown size, depth of rooting, genetic differences, physiological preconditioning of trees, and other causes. Furthermore, the environment influences cambial growth markedly in some parts of a tree and not others. Another problem in evaluating environmental control of tree growth is that a given degree of environmental stress has different effects at various times of the year. As Zahner and Stage (1966) cautioned, attempts to relate cambial growth to changes in weather often have not accounted for most of the observed growth variance when all weather measurements were treated as absolute values. This makes the point that a given amount of precipitation early in the growing season when soil moisture may be at field capacity will have little effect on cambial growth, whereas half that amount later in the season when the soil is dry will affect cambial growth markedly.

Internal control of tree growth has also been oversimplified by some investigators. For example, specific effects on cambial growth have often been linked to individual growth regulators, with an important role assigned to auxin. Several early investigators showed that exogenous auxin stimulated cambial division and subsequent differentiation of xylem cells. However, there often are problems in interpreting experiments involving a single applied growth regulator because it may stimulate metabolic activity to produce other internal growth regulators. It may also influence the activity of other growth regulators already present. Although auxin admittedly plays an important role in control of various aspects of cambial activity, normal cambial growth appears to be the end result of balances of several growth regulators (including growth promoters and inhibitors) and interactions among them (Kozlowski 1971b). Thus, we need to expand research directed toward elucidating the complex interactions and synergisms of internal growth control. This will call for well-equipped laboratories and combined talents of various specialists including anatomists, biochemists, physiologists and geneticists, working together with foresters concerned with practical field problems. And let me add forcefully that history teaches us that basic research leads to widespread application and basic research in forestry should not be depreciated because it sometimes appears impractical to some individuals. As a parallel, Kramer (1956) pointed out that medicine made its greatest progress when it began to concentrate on basic biochemistry and physiology.
Because of the complexity of tree growth, small, isolated laboratories without adequate library facilities and without access to the cross-fertilization of a community of scientists, will find themselves at a disadvantage. A recent report of the National Academy of Sciences (1966) emphasized that one of the most important needs in basic forestry research was its close correlation with research in other plant sciences. It specifically suggested that laboratories carrying out basic research in forestry should maintain very close contact with laboratories of related sciences. In cases in which field laboratories are geographically removed from the campuses of universities, special effort should be made to maintain close contact with the universities. This is essential for maintenance of stimulating contact with other related sciences, for access to libraries, and for teaching.

\section{Forest biology research in the future}

There will be no shortage of important problem areas in the immediate future. A more serious deficiency will be finding support for dealing with these problems. A few critical areas which should receive high-priority attention will be mentioned briefly. There are many other equally important problems in forest biology which directly or indirectly are involved in tree growth.

The environmental factors which are likely to receive increasing attention in the immediate future are various forms of pollution and water deficits.

Pollution. Forest biologists will have to give much attention to implications of environmental pollution in relation to tree growth. We can no longer count on trees growing in clean air. Now our environment is full of pollutants which affect tree growth and it appears that we will become even more polluted in the years to come. We will have to deal with effects of both primary and secondary pollutants. Sulfur dioxide, ozone, hydrogen fluoride, and peroxacetyl nitrate are considered the most important pollutants. However, aldehydes, chlorine, ethylene, hydrogen chloride, hydrogen sulfide, oxides of nitrogen, and silicon tetrafluoride are also toxic. The death and decline of trees from the effects of pollutants are well known, especially in the San Bernardino and San Gabriel mountains east of Los Angeles and in the vicinity of industrial centers in both Canada and the United States.

We know well that forestry and agriculture are a source as well as victim of pollution. The growing use of chemical technology for protection of trees and other crops from weeds, pests, and diseases also has serious effects on trees. A number of applied and naturally occurring chemical substances adversely affect seed germination and growth of trees. Such biocides include some insecticides, fungicides, and herbicides.

We have found that herbicides are variously toxic to germinating pine seeds and young seedlings. Toxicity symptoms resulting from overdosage, improper application, or use of the wrong herbicide include chlorosis, inhibition of cotyledon develop- 
ment, needle dieback, morphogenic changes (e.g cotyledon fusion, swollen stems) which affect the quality of planting stock. Herbicide toxicity varies greatly with method of herbicide application because of differences in herbicide losses leading to variation in herbicide uptake by seedlings.

We should stop pollution at its source, but as it seems unlikely that we will suddenly eliminate causes of pollution, forest biologists can meanwhile do much in identiifying and developing pollutionresistant trees. We have not even begun to characerize the full significance of pollution in terms of acute and chronic toxicity. We also need research on treatment of trees with materials that will prevent entry of pollutants into plants or detoxify the chemical. In addition we need to give more attention to naturally occurring toxic compounds present in aerial tissues or roots which leach out into the soil and influence growth of neighboring plants.

Water relations. It cannot be emphasized too strongly that although trees grow best in regimes of high and recurrent rainfall, all of them periodically undergo internal water stress. Water deficits tend to develop periodically in well-watered soils whenever transpiration exceeds absorption of water. In most parts of the United States and Canada soil moisture supplies are at optimal levels only rarely during the growing season and tremendous losses in growth result because of water deficits in trees. The staggering amounts of such losses often are not realized because data are not available to show how much more growth would occur if trees had favorable water supplies throughout the growing season. By altering chemical and physical composition of tissues, water deficits also modify various aspects of quality such as density of wood and taste of fruits. Growth limitations because of internal water deficits frequently are overlooked in situations where other deleterious agents operate including plant competition, disease, or insect pests. Stunting and killing of desirable trees by "weed competition" commonly involve competition for water leading to a desiccation effect. Root diseases and insect injury to roots often interfere with absorption of water and thereby cause desiccation of shoots. In vascular wilt diseases, the desiccation of tops following vascular plugging often plays a major role in foliage wilt and ultimate death of infected trees. Leaf desiccation causes considerable winter injury to evergreens. During some warm winter or spring days transpiration is appreciable but water cannot be absorbed readily from cold or frozen soils and leaves consequently dry out. Water deficits also play an important role in predisposing host plants to attacks by certain fungus pathogens and insects (Kozlowski 1968).

It is still extremely difficult to appraise clearly the mechanism of water deficits on growth of trees in the field. One reason for this is that the internal water status of trees is a dynamic parameter, influenced by conditions in the soil and atmosphere and regulated to various degrees in different situations and with different species by physiological factors. Hence, internal water balance is difficult to examine experimentally. Another problem is that internal water deficits affect tree growth in many ways, both directly and indirectly. Hence, cause and effect relationships are not easily established.

Finding a way to maintain a favorable internal water balance of forest trees at critical times (e.g., following transplanting) is a problem of paramount importance and should be vigorously researched. Much apparent drought resistance is traceable to deep and branched root systems of plants. Hence, plant breeders might well give attention to development of seedlings with deeply penetrating and profusely branching root systems. Other possibilities include producing plants with thick cutin and very responsive stomata which will conserve water during short droughts. Reducing energy absorption by modifying leaf color or leaf arrangement might also be helpful.

Physiologists should also work energetically to find antitranspirants which will reduce transpiration and not be toxic. Many leaf coatings which control transpiration chiefly by physically blocking the stomata have proved disappointing. They often reduce transpiration but also inhibit photosynthesis and eventually kill outplanted trees. The relatively recent finding that some antitranspirants which operate as metabolic inhibitors can prevent opening of stomata have proved disappointing. They often reopen stomates was a very significant contribution. Unfortunately, some of the metabolic inhibitors which induced stomatal closure in herbaceous plants are variously toxic to both gymnosperm and angiosperm trees (Kozlowski and Clausen 1970). Thus, the problems of dosages and kinds of chemicals to use are many. Nevertheless, because the stakes are so high and because it has been demonstrated that stomata can be closed for periods of up to a few weeks by metabolic inhibitors, we need to continue research along these lines.

Quality of planting stock. Much can be done by geneticists, tree breeders and physiologists to develop grades of nursery stock with high survival and growth potential. An extensive literature is available on relations of certain morphological features of graded nursery stock to growth and survival after outplanting. Critical age and size of seedling have been used most commonly in establishing criteria for grading of plantable seedlings. The very important work of Wakeley (1954) with southern pines showed that data from trials with morphological grades have been exceedingly variable, with results influenced by species, site, year of planting, and other factors. For a few years after outplanting, morphological grading seemed satisfactory. During the first 5 years after outplanting, transplants of the higher morphological grades showed increased growth and survival over lower grades. However, with wider applications, stock graded as plantable often showed low survival. These important experiments demonstrated that critical internal physiological conditions of seedlings, which have not always been easily identified, often greatly out- 
weighed morphological grades in influencing growth after outplanting.

Experiments are needed concerning relations of food reserves, homonal growth regulators, nutrient balance, and water stress to response of seedlings after transplanting. A subsequent obvious need is to work out nursery regimes that will produce such high physiological grades of planting stock. Particular attention is called to the very important research in California by E. C. Stone and his colleagues on factors controlling root regeneration potential of nursery stock.

Reproductive growth. One of our most serious deficiencies is lack of understanding of reproductive growth. Once the juvenile stage of growth is passed and the capacity for reproductive growth is achieved by a tree, it is usually retained thereafter. Nevertheless, reproductive growth of many adult trees is disturbingly irregular. Failure of a fruit or seed crop in adult trees results all too often from internal blocks at one or more of the sequential phases of reproductive growth such as floral induction, flowering, pollination, fertilization, embryo growth, or fruit and seed ripening. Although much is known about combinations of environmental factors which favor various stages of reproductive growth, the nature of the internal controls through which environmental factors are mediated is not so well understood.

We need to study in detail the entire sequence of events which culminate in production of the mature seed. As Romberger (1967) pointed out, a concerted effort, using both methods of molecular and developmental biology, is needed to study the partial processes of reproduction. The goal of such research may be to control the process - its suppression generally and its induction in selected individuals at will. Possibly we need a separate major laboratory, with a mix of talents, working on reproductive physiology of trees.

\section{Controlled-environment facilities}

In planning future research forest biologists should give careful thought to the values of phytotrons. These are laboratories composed of controlled environment facilities, chambers, and greenhouses used simultaneously in various combinations to study the effects of environment on plants. The many carefully controlled environmental combinations that are available in such a facility make it possible to study environmental factor action and interaction with high accuracy and within a reasonable length of time. Phytotrons offer several advantages in research over field conditions, green-

\section{Literature cited}

KOZLOWSKI, T. T. (Ed.) 1968. Water deficits and plant growth. Vol. I. Development, control and measurement. Academic Press, N.Y.

KOZLOWSKI, T. T. 1971a. Growth and development of trees. Vol. I. Seed germination, ontogeny and shoot growth. Academic Press, N.Y.

1971b. Growth and development of trees. Vol. II. Cambial growth, root growth and reproductive growth. Academic Press, N.Y.

KOZLOWSKI, T. T. and J. J. CLAUSEN. 1970. Effect of decenylsuccinic acid on needle moisture content and shoot growth of Pinus resinosa. Can. J. Plant Sci. 50: 355356. houses, or even small groups of controlled environment chambers. A phytotron can be used to dissect or construct a given environment. Growth responses over a wide range of given environmental factors can be obtained concurrently. Interaction of 2 or more factors can be studied while holding other factors relatively constant. A given set of environmental conditions can be produced on demand. Phytotrons can be used to select climatic regions in which to field-test new species and varieties or to assist in the selection of plants for use in specific climates.

\section{Research support}

Until recent years research in forest biology lagged badly behind other types of biological research. A National Academy of Sciences Report (1966) on "The Plant Sciences Now and In the Coming Decade" urgently pleaded for increased support of research in forest biology in the United States. It stated that in 1960 all research and development amounted to $2.5 \%$ of the gross national product. By comparison, the cost of forestry research was only $0.35 \%$ of the money the timber industry alone contributed to the gross national product.

Because of its nature it is essential that forestry research have adequate and continuous funding. Unlike the situation with some other aspects of forest biology, many genetics experiments with forest trees cannot be easily turned on and off or postponed after they are once started. Even with stability of personnel and support, the long risk period between establishment and completion of experiments makes them very failure-prone. It has been estimated that half to three-fourths of potential research information in forest genetics has been lost as a result of personnel changes, administrative inconsistencies, and damage due to low-probability disasters. Libby et al. (1969) suggested that as an antidote for all this, attention be given to conducting major experiments as line projects, with new personnel becoming identified with going projects. Under such a system, the scientific freedom of the individual scientist might be curtailed somewhat but, by compensation, research data would tend not to be lost, even with personnel changes. There would also be protection for budgets as these would not necessarily be wholly identified with individuals. In addition, it would be desirable for the biologist working as part of a team on a going project, to work on other projects wholly under his supervision.

KRAMER, P. J. 1956. The role of physiology in forestry. Forest. Chron. 32: 297-308.

LIBBY, W. J., R. F. STETTLER and F. W. SEITZ. 1969. Forest genetics and forest tree breeding. Ann. Rev. Genet. 3: 469-494.

NATIONAL ACADEMY OF SCIENCES. 1966. The plant sciences now and in the coming decade. Nat. Acad. Sci., Nat. Res. Counc., Washington, D.C. 167 p.

ROMBERGER, J. A. 1967. Flowering as a problem in developmental physiology. XIV IUFRO Congress: 1-14.

WAKELEY, P. F. 1954. Planting the southern pines. USDA Forest Serv. Agr. Monogr. No. 18.

ZAHNER, R. and A. R. STAGE. 1966. A procedure for calculating daily moisture stress and its utility in regressions of tree growth on weather. Ecology 47: 64-74. 